\title{
Relevance in Education?
}

\author{
David Zeigler
}

Published online: 30 August 2008

(C) Springer Science + Business Media, LLC 2008

Among a number of other questionable "ideals" that have become commonplace in educational philosophy over the past few decades, relevance is one that has been preached and applied widely. Make the material relevant to the student in any way possible - that is the message, and it is typically implied that any topic worth learning can be made relevant to the average student if the teacher simply tries hard enough. Unfairly as usual, the emphasis is always on the effort of the teacher as the key to success. An endpoint to this and other educational "tricks" (co-operation, selfexpression, etc.) is never discussed, rather it is implied that what works in grade school should continue to be applied and carried right through the college years, regardless of the fact that most jobs in the real world require independent work and achievement, with relevance and self-expression ranking low in the average workplace.

I see no problem in using some of these once nontraditional educational ideas in moderation in the lower grades to "engage" students and show them that learning can sometimes be fun, but real academic learning does and must always involve some level of work - the "W-word" that is so widely avoided in our modern society. In fact, the work level should rightly be expected to increase as one moves up the grade scale and into college. Certainly, past the freshman year of college, students should have become at least somewhat self-motivated and driven and no longer need tricks and entertainment value artificially added to most of their coursework. They should move (and be moved) to the level of adult interaction where they can easily listen to a presentation, make obvious connections,

D. Zeigler $(\bowtie)$

The University of North Carolina at Pembroke,

Pembroke, NC, USA

e-mail: David.zeigler@uncp.edu ask meaningful questions, and take responsibility for their own learning.

When I attend national scientific meetings featuring distinguished guest speakers, those speakers almost always deliver well-planned lectures supported by Powerpoint visuals (typically around an hour long), which those in attendance feel privileged to hear and then have the opportunity to interact with questions. I would hope that our universities want to graduate students who would be able to attend such meetings and possess the attention span to follow and actually enjoy such quality presentations within their chosen fields. If they still need to be entertained and asked their opinions throughout such a lecture, they simply are not adult learners and have not "graduated" into the world of serious adult learning.

In the sciences, much of what is learned and questioned is simply not directly relevant to the student or even to humanity. This is undoubtedly a major reason why many in the "me generation" have garnered a dislike for sciencebecause it is not about them. Most other disciplines (business, history, art, economics, literature, languages, sociology, philosophy, etc.) are human-centered, whereas much of science is not, except for the pure pleasure of using one's curiosity to gain knowledge about the real world and universe in which we live in.

What is or could be relevant to modern students concerning dinosaurs that have been extinct for $65,000,000$ years or more? Except for the few whose goals involve dinosaur research or art (certainly less than $1 \%$ of students), there is really nothing directly relevant about dinosaurs except that they were simply some of the most magnificent and interesting beasts ever to have walked the earth. Many great scientists (such as Stephen J. Gould) credit an early interest in dinosaurs as instrumental in their decision to become scientists. I recently attended an IMAX 
film about dinosaurs where around $70 \%$ of the audience was made up of children who were most definitely excited by the presentation. Fortunately, children are innately curious about a great many things outside themselves, but the current pressures to make learning personally relevant works against that wonderful and open trait of childhood. Curiosity about the world is what drives interest in the sciences-not personal relevance.

Allowing students the opportunity to hold an actual fossil in their hands and discuss what it is could add some level of relevance to a discussion of extinct life forms. Going to a local site and actually digging out some fossils would surely add another level of relevance - as in "these things actually occur around here." But such opportunities are not readily available to all, and not all locations will have ready access to fossil beds, museums, telescopes, shorelines, zoos, public aquaria, and other first-hand opportunities for adding more relevance to their science courses. This is especially true in most K-12 classes.

Whether it be evolution, fossil finds, or any other area of science, another great aid in making a topic relevant is to cite current finds, especially those that are significant to the material being covered. I recently incorporated into my marine biology course the discovery of extant living reefs made of glass sponges off the coast of British Columbia (Dybas 2008). Though the fossil record shows that such reefs existed in the distant past, these sizable reefs of glass sponges (some up to $18 \mathrm{~m}$ high and hundreds of square kilometers in footprint) are the first to have been discovered in modern times. This discovery, of course, makes a strong contrast to the idea that all reefs are coral reefs, and more importantly, it illustrates that major discoveries concerning biodiversity continue to take us by surprise - reformulating our understanding of the planet. A major message of science is that much about our world and universe is still unknown, and many discoveries await us in the future. Carl Sagan is reported to have said: "Somewhere there is something incredible waiting to be known." Most agree that people love discovery and adventure, and it really should not take extreme measures to make the discoveries of science exciting to the average young person.

Current recommendations concerning the teaching of evolution include attempts to make evolution relevant by addressing topics like the evolution of antibiotic resistance by bacteria and the evolution of the AIDS virus - topics that do concern humans today, but these topics pale in comparison in both scope and fascination to the rapid multiplication of cichlid species in Lake Victoria and Lake Malawi, the evolution of anole lizards in the islands of the Caribbean, and the relatively recent evolution of the endemic Galapagos flora and fauna. Likewise, the recently filled in details of the evolution of the first land vertebrates and the whales from terrestrial ancestors are topics most people should be curious about.
All that most topics really require to make them interesting to others is a teacher who exudes a fascination and interest in the topic. If a teacher does not show excitement, interest, and pleasure in the topics they cover, that lack will undoubtedly hinder student engagement. Especially in the sciences, teachers should be both masters and lovers of the material they are teaching. E.O. Wilson said it well when he wrote: "Returning to passion as the driver of learning, a teacher's dedication is most effective when expressed through both the art of teaching and the demonstrated love of the subject for its own sake" (Wilson 2006). Showing a passion for the topic is in itself a way to make a topic relevant, as in-some people are really excited about these topics.

As mentioned above, curiosity and an interest in our world is the innate norm among humans (especially in children) - a point that has been realized by many writers and scientists:

- "All men by nature desire to know." (Aristotle 1996)

- "A young child is born with the capacity for true learning; the openness, integrity, and the unbounded curiosity that should become his lifetime way to knowledge." (Wylie 1968)

- "We are all born curious, full of questions, with an open mind and a built-in sense of awe and wonder about life." (Pine 1989)

- "Many of these children (kindergarten and first graders) are natural-born scientists - although heavy on the wonder side and light on skepticism. They're curious, intellectually vigorous." (Sagan 1997)

It is only through the damping of their curiosity by adults (unfortunately sometimes educators) that many children completely lose this sense of wonder and come to demand personal relevance in its place. Most scientists would say that curiosity should trump relevance every time. Curiosity leads to open-mindedness and critical thinking, qualities every educator should want students to possess and develop. Extreme emphasis on relevance can potentially lead to self-centered narcissism - the extreme opposite of open curiosity. This point is made by Maureen Stout in her book The Feel Good Curriculum (Stout 2000). Two quotes from her book plainly state the problems with relevance: (1) "If we only learned what we were sure was relevant, we'd never learn anything." (2) "Education should be about discovering the world, not just discovering oneself."

Of course, there are many societal factors that contribute to the disinterest or smug apathy seen in many of today's students: single-parent homes, poverty, a lack of encouragement to read at home, television (the great majority of it), videogames, drugs, entitlement philosophy, lowered educational standards, the belief in success without effort, 
fear of being labeled a nerd, postmodern deconstructionist philosophy, etc. Teachers are up against all this and more, and most of these factors cannot be totally overcome by good teachers, but surely knowledgeable and passionate teachers have to be part of the solution for creating students who are again excited about learning.

Did the great naturalists like Darwin, Lyell, Wilson, etc. see personal pragmatic relevance in their chosen subjects of study, or did they choose based on sheer curiosity and the desire to learn something previously unknown? Galileo not only profited little from his life's work; he was actually persecuted for his findings concerning the structure of the solar system. The world and universe are actually still little known, and the opportunity for discovery is still very great for those who find the world fascinating. Howard Ensign Evans (a famed entomologist) wrote: "The earth has spawned such a diversity of remarkable creatures that I wonder why we do not all live in a state of perpetual awe and astonishment" (Evans 1968).

I know some teachers who have read this far will still argue that some of their students simply need an added dose of relevance to make them pay attention and express any signs of interest in the material. As a biologist, I can only say that I strongly feel I owe the material (the content) of what I teach the honor of not diluting it too far. The content of biology is too important, fascinating, and hard-won to subject it all to a test of personal relevance for every student. There is no reason to expect every child to be fascinated with science just as there is no reason to expect every child to love art. We preach the importance of diversity, yet we contradict ourselves when we expect all students to be engaged with science, and of course realistically - we do not. If we frantically search for the few nuggets of information that all or most students will or can learn (which of course will neglect vast amounts of more complex and fascinating material that science or any discipline has to offer), we will have done a great disservice to our discipline- - I feel especially so in the sciences.

I make every attempt to direct my students in biology away from the human-centered view that pervades so much of what people think about and pursue. I would say that it is precisely this view (I call it the "it's all about us" worldview) that has resulted in an overpopulated planet where species are going extinct every day due to our selfish and short-sighted views of life-views that are nevertheless personally relevant to those caught up in civilization's virtual reality. Unquestionably and sadly, the majority of people view the natural world as a resource for human consumption. Even conservationists by definition are those who want to conserve something that we may eventually need to use. If you drive at $60 \mathrm{mph}$ to conserve your gas, you will still use it up, only not as rapidly as you would at $70 \mathrm{mph}$. Only the philosophy of preservation views nature as having intrinsic value-something that deserves the right to exist apart from our pragmatic use of it. It is hard to be fascinated or curious about "a resource," but easy to have these feelings about a world you feel has intrinsic value apart from humanity. Curiosity and appreciation for the natural world is what I want to develop and instill in my students. For a good biologist, personal relevance is not very important unless it comes in the form of a personal fascination with the natural world-even love of the natural world.

It is hard enough to convince people today that we might want to reconsider our wild technological ride and the kind of world we will leave to our grandchildren. If they have been taught year after year throughout most of their school years that everything worth learning is or should be relevant to them personally - or even to humanity generally, then I fear greatly for the future of biodiversity but just as greatly for the nature of future humans because they will have devalued or even lost the natural curiosity that drives science, critical thinking, life-long learning, and a true appreciation of the world and universe we inhabit.

\section{References}

Aristotle. Metaphysics, books I-IX. Cambridge, MA: Harvard University Press; 1996.

Dybas CL. Deep sea lost and found. Bioscience 2008;58(4):288-94. Evans HE. Life on a little-known planet. New York, NY: Delta; 1968. Pine RC. Science and the human prospect. Belmont, CA: Wadsworth; 1989.

Sagan C. The demon-haunted world: science as a candle in the dark. New York, NY: Ballantine Books; 1997.

Stout M. The feel-good curriculum. Cambridge, MA: Perseus Publishing; 2000.

Wilson EO. The Creation. New York, NY: W.W. Norton \& Company; 2006.

Wylie P. The magic animal. Garden City, NY: Doubleday; 1968. 